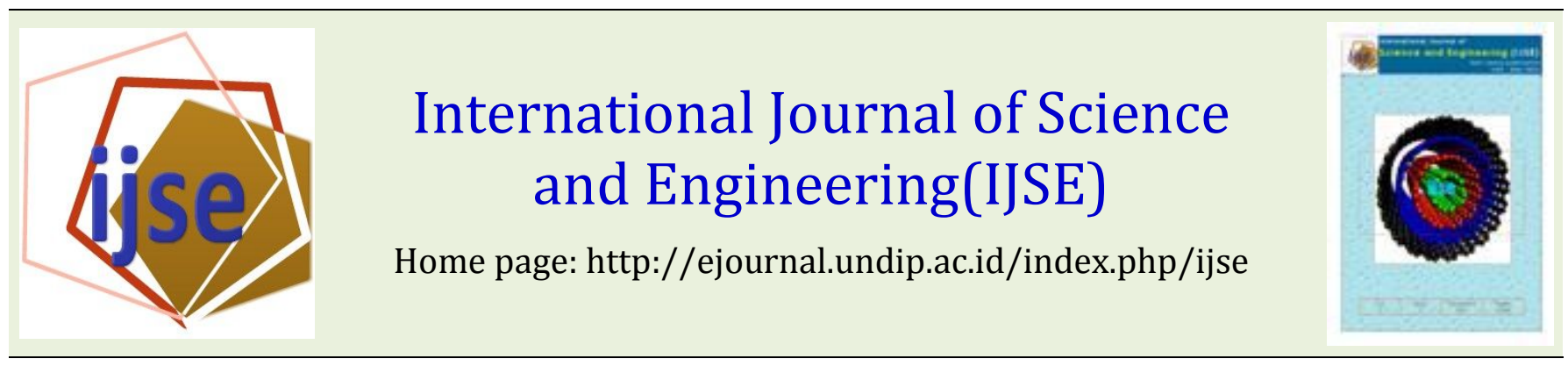

\title{
The Influence of Malt Extraction Adding to UF Fresh Low Fat Cheese on Its Textural Properties
}

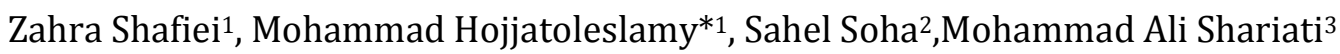 \\ ${ }^{1}$ Department of Food Science and Technology, Faculty of Agriculture, Islamic Azad University, Shahrekord Branch, \\ Shahrekord,Iran. \\ ${ }^{2}$ Researcher of Institute of Standards and Industrial Research of Iran ,Arak, Iran. \\ ${ }^{3}$ Department of Food Science and Technology, Science and Research Branch, Islamic Azad University, Tehran, Iran. \\ Corresponding Author:mohojjat@iaushk.ac.ir
}

\begin{abstract}
Today, demands for reduced fat products such as reduced fat cheeses is growing as it has shown in other food products , however high nutritional value of milk fat as a functional food can't be ignored. This study deals with investigation of adding malt extract ( in 4 different concentration $0.075,0.1,0.15$ and $0.2 \%$ ) to ultra filtered cheese and comparing them with 2 control including a sample produced of milk containing $3.5 \%$ fat and a $0.93 \%$ fat and their rheological and textural properties evaluated at $3,20,40$ and 60 days. Results indicate reduction of texture properties revealed. Rheological analysis exhibited the texture improvement by adding malt extraction; therefore this product can be use an additive to ultra filtered cheese to enhance its texture.
\end{abstract}

Keywords-Model Low Fat Cheese, Texture, Malt Extraction, UF fresh cheese

Submission: 27 November 2013

Corrected : 28 December 2013

Accepted: 4 January 2014

Doi: DOI: $10.12777 /$ ijse.6.1.52-55

[How to cite this article: Shafiei, Z.,Hojjatoleslamy, M., Soha, S.,and Shariati, M.A. 2014. The Influence of Malt Extraction Adding to UF Fresh Low Fat Cheese on Its Textural Properties. International Journal ofScienceandEngineering, 6(1):57-60. Doi: 10.12777/ijse.6.1.52-55

\section{Introduction}

UF fresh cheese has a soft, spreadable texture produced by ultra filtration of milk to reach $35 \%$ dry solid and then enzyme coagulation of retentate. Two month shelf life, final $\mathrm{pH} 4.8$, having 45-60\% fat in dry solid in final products are some properties of this cheese, therefore consuming it cause to increase the level of fat in consumers $(1,3,15)$. Fat has both nutritional and textural role in cheese.And low fat cheeses contain deficits including hard and elastic texture, weak melt ability and inappropriate color and flavor(11)as a results of resulted more compressed protein matrix and more brittle cheese texture $(10,16)$. To improve cheese texture, different ways are placed into 3 categories including modifying of usual technology of cheese making, application of suitable fat replacer to improve creaming texture and appropriate culture media which produce exopolysaccaharides(16). Miocinovic et al. studied of using Inulin in low fat ultra filtered cheese and reported that low fat cheese without Inulin contained big holes while adding it caused to a creamy and compressed texture (13). Applying Barley $\beta$-glucan concentrate as a fat replacer on physiochemical and functional properties of low-fat Mozzarella cheese exhibited more moisture and a softer texture in final products(20). Lobato-Calleros et al , used a complex of emulsion of different hydrocolloids such as Carboxymethyle cellulose, Arabic Gum and pectin. Among them CMC led to high fat texture-like properties in produced cheese (12). Adding malt extraction to Domiati cheese resulted in a slight increasing of moisture and acidity, more lypolyse and proteolyse along with more bacterial count overall flavor enhancement and textural properties of cheese(1). This study aims at improving technological and functional properties of low fat ultra filtered cheese by adding malt extraction.

\section{Materials and Methods}

To investigate of different concentration of malt extraction, six treatment produced and coded as follows: SFC: cheese produced by whole milk contains $3.5 \%$ fat LFS: cheese produced by milk contains $0.93 \%$ fat without malt extraction 
X1: cheese produced by milk contains $0.93 \%$ fat and adding $0.075 \%$ malt extraction

X2: cheese produced by milk contains $0.93 \%$ fat and adding $0.1 \%$ malt extraction

X3: cheese produced by milk contains $0.93 \%$ fat and adding $0.15 \%$ malt extraction

X4: cheese produced by milk contains $0.93 \%$ fat and adding $0.2 \%$ malt extraction

Cow milk, malt extract and culture media FRC-65 purchased from Golpayegan city ,Isfahan province of Iran , ZgrosJahanbin Co and Chr, Hansens Dairy Cultures, Denmark respectively.FRC-65 culture media consists of Lactococcuslactis subsp. Cremoris Streptococcus thermophilus, Lactobacillus delbrueckii subsp. Bulgaricus. To create curd ,Fromase 2200 TL Granulate(D.M.S Co Australia ) used.

\section{UF Cheese Preparation}

First, raw milk passed through, chiller,clarifier, bactofugationsystem, then pasteurized at $72^{\circ} \mathrm{C}$ for $15 \mathrm{~s}$ and its water, lactose and minerals removed by tubular membrane filters, resulted retentate homogenized at 55 ${ }^{\circ} \mathrm{C}$ and $70 \mathrm{psi}$, pasteurized at $78{ }^{\circ} \mathrm{C}$ for $1 \mathrm{~min}$, then cooled to $37{ }^{\circ} \mathrm{C}$ and inoculated by adding $1 \%$ starter.Malt extract added in 5 levels including $0,0.075,0.1,0.015$ and 0.2 to retentate. Retentate passed through curd tunnel (30 $\mathrm{min}$, $30{ }^{\circ} \mathrm{c}$ ), then placed in incubator at $25-30{ }^{\circ} \mathrm{C}$ for $24 \mathrm{hr}$. Produced samples placed in refrigerator 60 days at 8$10^{\circ} \mathrm{C}$ in order to investigate their textural properties .

\section{Texture Profile Analysis (TPA)}

Brookfield engineering, Middleboro, USA equipped with a TA 3/1000 probe was used to conduct TPA evaluation of Controls and treatments in 3,20,40 and 60 days of storing.Cheese samples cut into $20 \times 20 \times 20 \mathrm{~mm}$, compressed to $50 \%$ of initial height $(10 \mathrm{~mm})$ in 2 cycles .penetration rate was $0.5 \mathrm{~mm} / \mathrm{s}$ and each test was performed in 3 replicates the evaluated properties were Hardness , Cohesiveness, Springiness, Chewiness , Gumminess and Adhesiveness (5,7).To perform cutting test former device equipped with a TA /53 probe and required force to cut in depth of $15 \mathrm{~mm}$ measured .And each samples test performed in 3 replicates. A TA /40 probes used for punching test and the required force of punching metal rod in depth of $10 \mathrm{~mm}$ measured. Other conditions were the same as other tests (5).Results analyzed by ANOVA and Duncan tests by SPSS V.20 software.

\section{Results and discussions Hardness}

Table 1 shows the TPA results of fresh samples. Hardness define as required force of compressing cheese between milling teeth (for hard and semi hard cheeses) or between tongue and palate ( for soft and spreadable cheeses ).Water, protein and fat influence hardness of cheese (18). Protein dominance in low fat cheese results in introducing more hardness and elastic like texture $(14,16)$. The most and the least evaluated hardness wererelated to LFS and X4 respectively. Increasing malt extract is thought to result in reduction of hardness (Fig $1)$. These results are in agreement with Romeih et al. (2002) and Koca et al. (2004). Moisture increased the plasticity of protein matrix and decreased its elasticity made it ready to be disrupted in compressing, entrapped water molecule inside of 3 dimensional protein matrix, therefore weaken and soften the texture.

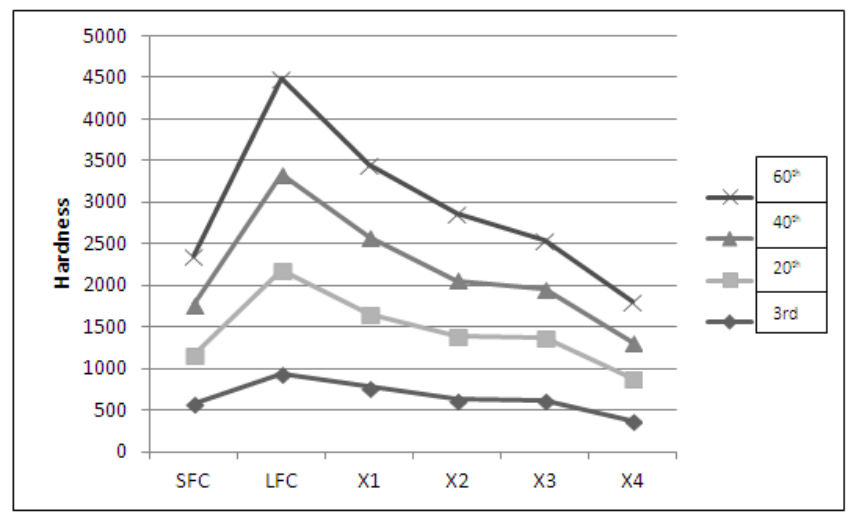

Fig.1.Effect of malt extract on hardness of UFfresh low fat cheese at $3^{\text {rd }}, 20^{\text {th }}, 40^{\text {th }}$ and 60 th days of storing

\section{Cohesiveness}

Cohesiveness define as the amount of created deformation by milling teeth compressing before cutting occurs, mostly depends on molecules links $(5,7,19)$. The most and the least cohesiveness were related to LFS and SFC respectively $(\mathrm{p}<0.05)$.it is thought that due to fat reduction $(4,16,17)$.All the results are in agreement with Volikakis et al. (2004). Weakness of inside links is the main important reason of cohesiveness reduction observed in low fat cheese which deformed irreversibly by TPA device. This reduction also can increase proteolyses and softening of cheese.

\section{Springiness}

Springiness implies the elasticity of sample in which more springiness causes to more elasticity. The most amount of this parameter related to the low fat treatment $(5,19)$. The most amount of springiness related to the low fat treatment .results were in agreement with Koca et al , 2004; Romeih et al ,(2002).It is found that malt extract resulted in moisture absorption, reduction of hardness and less ability to initial shape when removing force(15).

\section{Chewiness}

When fat reduced, chewiness increased significantly respect to SFC (in agreement with Volikakis et al.,2004 ).It is thought that more moisture content as a result of water binding by adding malt extract to cheese has been weakened the texture and decreased the required force of cracking samples $(5,21,19)$.

\section{Gumminess}

Table 2 shows the results of Gumminess test.The amounts of Gumminess in LFC was significantly more than SFC ( $p>0.05)$. This results were in agreement with Romeih et al, 2000. More malt extract, less Gumminess in 
produced cheese may arise from increasing moisture content 'cause of capacity of malt absorbing water $(12,17,19)$.

\section{Adhesiveness}

Table.1.Comparison of averages of different malt extraction concentration on textural properties of UF fresh cheese

\begin{tabular}{|c|c|c|c|c|c|}
\hline Samples & Parameter & & & Day & \\
\hline SFC & $\begin{array}{c}\text { Hardness(gr) } \\
\text { Cohesivene }\end{array}$ & $\begin{array}{c}3 \\
580 / 75 \pm 31 / 75^{\mathrm{b}} \\
0 / 24 \pm 0^{\mathrm{a}}\end{array}$ & $\begin{array}{c}20 \\
577 / 66 \pm 89 / 39^{\mathrm{a}} \\
0 / 22 \pm 0 / 062^{\mathrm{a}}\end{array}$ & $\begin{array}{c}40 \\
600 / 75 \pm 2 / 75^{\mathrm{b}} \\
0 / 21 \pm 0 / 015^{\mathrm{a}}\end{array}$ & $\begin{array}{c}60 \\
597 / 75 \pm 55 / 25^{\mathrm{a}} \\
0 / 19 \pm 0 / 025^{\mathrm{a}}\end{array}$ \\
\hline & $\begin{array}{c}\text { Spriniginess }(\mathrm{mm}) \\
\text { Chewiness (gr) } \\
\text { Guminess (gr) } \\
\text { Adhesiveness (gr) }\end{array}$ & $\begin{array}{c}5 / 96 \pm 0 / 10^{\mathrm{a}} \\
8 / 15 \pm 0 / 26^{\mathrm{a}} \\
139 / 60 \pm 6 / 80^{\mathrm{a}} \\
0 / 46 \pm 0 / 26^{\mathrm{ab}}\end{array}$ & $\begin{array}{c}7 / 51 \pm 0 / 83^{\mathrm{ab}} \\
9 / 81 \pm 5 / 30^{\mathrm{a}} \\
129 / 46 \pm 55 / 36^{\mathrm{a}} \\
1 / 20 \pm 0 / 56^{\mathrm{a}}\end{array}$ & $\begin{array}{c}5 / 73 \pm 1 / 24^{\mathrm{a}} \\
7 / 41 \pm 2 / 17^{\mathrm{a}} \\
129 / 60 \pm 10 / 70^{\mathrm{ab}} \\
0 / 60 \pm 0 / 075^{\mathrm{a}}\end{array}$ & $\begin{array}{c}6 / 40 \pm 0 / 11^{\mathrm{a}} \\
7 / 16 \pm 0 / 070^{\mathrm{a}} \\
114 / 00 \pm 3 / 20^{\mathrm{a}} \\
3 / 18 \pm 0 / 30^{\mathrm{b}}\end{array}$ \\
\hline LFC & $\begin{array}{c}\text { Hardness (gr) } \\
\text { Cohesivene } \\
\text { Spriniginess(mm) } \\
\text { Chewiness (gr) } \\
\text { Guminess (gr) } \\
\text { Adhesiveness (gr) }\end{array}$ & $\begin{array}{c}945 / 37 \pm 3 / 62^{\mathrm{d}} \\
0 / 36 \pm 0 / 020^{\mathrm{b}} \\
10 / 08 \pm 0 / 40^{\mathrm{c}} \\
34 / 92 \pm 3 / 24^{\mathrm{d}} \\
341 \pm 52 \pm 17 / 47^{\mathrm{e}} \\
0 / 45 \pm 0 / 068^{\mathrm{ab}}\end{array}$ & $\begin{array}{c}1235 \pm 128 / 50^{\mathrm{d}} \\
0 / 24 \pm 0 / 020^{\mathrm{a}} \\
8 / 25 \pm 0 / 26^{\mathrm{b}} \\
23 / 42 \pm 0 / 31^{\mathrm{c}} \\
289 / 60 \pm 5 / 30^{\mathrm{b}} \\
0 / 66 \pm 0 / 035^{\mathrm{a}}\end{array}$ & $\begin{array}{c}1146 / 66 \pm 165 / 68^{\mathrm{d}} \\
0 / 19 \pm 0 / 040^{\mathrm{a}} \\
7 / 94 \pm 0 / 76^{\mathrm{a}} \\
17 / 55 \pm 3 / 55^{\mathrm{c}} \\
229 / 36 \pm 64 / 81^{\mathrm{cd}} \\
1 / 07 \pm 0 / 92^{\mathrm{a}}\end{array}$ & $\begin{array}{c}1161 / 33 \pm 147 / 41 \\
0 / 18 \pm 0 / 058^{\mathrm{a}} \\
7 / 47 \pm 0 / 12^{\mathrm{b}} \\
15 / 49 \pm 3 / 92^{\mathrm{b}} \\
210 / 93 \pm 50 / 13^{\mathrm{bc}} \\
0 / 85 \pm 0 / 0057^{\mathrm{a}}\end{array}$ \\
\hline $\mathbf{X}_{2}$ & $\begin{array}{c}\text { Hardness }(\mathrm{gr}) \\
\text { Cohesivene } \\
\text { Spriniginess }(\mathrm{mm}) \\
\text { Chewiness (gr) } \\
\text { Guminess (gr) } \\
\text { Adhesiveness (gr) }\end{array}$ & $\begin{array}{c}626 / 50 \pm 30 / 45^{\mathrm{b}} \\
0 / 35 \pm 0 / 036^{\mathrm{b}} \\
7 / 86 \pm 0 / 90^{\mathrm{b}} \\
17 / 21 \pm 3 / 83^{\mathrm{b}} \\
221 / 36 \pm 25 / 58^{\mathrm{b}} \\
0 / 44 \pm 0 / 13^{\mathrm{ab}}\end{array}$ & $\begin{array}{c}765 / 00 \pm 13 / 00^{\mathrm{bc}} \\
0 / 36 \pm 0 / 010^{\mathrm{c}} \\
7 / 80 \pm 1 / 27^{\mathrm{ab}} \\
21 / 16 \pm 3 / 68^{\mathrm{bc}} \\
276 / 10 \pm 3 / 20^{\mathrm{b}} \\
0 / 69 \pm 0 / 40^{\mathrm{a}}\end{array}$ & $\begin{array}{c}663 / 16 \pm 36 / 08^{\mathrm{b}} \\
0 / 26 \pm 0 / 015^{\mathrm{ab}} \\
8 / 23 \pm 2 / 82^{\mathrm{a}} \\
14 / 30 \pm 4 / 61^{\mathrm{bc}} \\
178 / 13 \pm 11 / 85^{\mathrm{bc}} \\
1 / 49 \pm 1 / 90^{\mathrm{a}}\end{array}$ & $\begin{array}{c}813 / 66 \pm 107 / 13^{\mathrm{b}} \\
0 / 32 \pm 0 / 026^{\mathrm{c}} \\
7 / 72 \pm 0 / 29^{\mathrm{b}} \\
19 / 82 \pm 3 / 26^{\mathrm{c}} \\
263 / 03 \pm 51 / 97^{\mathrm{b}} \\
0 / 62 \pm 0 / 44^{\mathrm{a}}\end{array}$ \\
\hline $\mathbf{X}_{\mathbf{3}}$ & $\begin{array}{c}\text { Hardness }(\mathrm{gr}) \\
\text { Cohesivene } \\
\text { Spriniginess }(\mathrm{mm}) \\
\text { Chewiness }(\mathrm{gr}) \\
\text { Guminess }(\mathrm{gr}) \\
\text { Adhesiveness }(\mathrm{gr})\end{array}$ & $\begin{array}{c}622 / 00 \pm 43 / 89^{\mathrm{b}} \\
0 / 34 \pm 0 / 047^{\mathrm{b}} \\
7 / 71 \pm 1 / 06^{\mathrm{b}} \\
16 / 19 \pm 2 / 40^{\mathrm{b}} \\
214 / 40 \pm 14 / 86^{\mathrm{b}} \\
1 / 22 \pm 0 / 37^{\mathrm{bc}}\end{array}$ & $\begin{array}{c}744 / 83 \pm 24 / 87^{\mathrm{b}} \\
0 / 30 \pm 0 / 011^{\mathrm{b}} \\
7 / 25 \pm 0 / 66^{\mathrm{ab}} \\
15 / 96 \pm 1 / 23^{\mathrm{b}} \\
241 / 56 \pm 40 / 92^{\mathrm{b}} \\
0 / 29 \pm 0 / 14^{\mathrm{a}}\end{array}$ & $\begin{array}{c}590 / 83 \pm 59 / 03^{\mathrm{b}} \\
0 / 23 \pm 0 / 072^{\mathrm{a}} \\
7 / 29 \pm 0 / 64^{\mathrm{a}} \\
10 / 18 \pm 5 / 07^{\mathrm{ab}} \\
139 / 30 \pm 57 / 98^{\mathrm{ab}} \\
0 / 10 \pm 0 / 092^{\mathrm{a}}\end{array}$ & $\begin{array}{c}581 / 50 \pm 98 / 00^{\mathrm{a}} \\
0 / 27 \pm 0 / 030^{\mathrm{bc}} \\
6 / 01 \pm 0 / 75^{\mathrm{a}} \\
9 / 32 \pm 1 / 81^{\mathrm{a}} \\
157 / 03 \pm 11 / 66^{\mathrm{ab}} \\
0 / 22 \pm 0 / 025^{\mathrm{a}}\end{array}$ \\
\hline $\mathbf{X}_{4}$ & $\begin{array}{c}\text { Hardness }(\mathrm{gr}) \\
\text { Cohesivene } \\
\text { Spriniginess }(\mathrm{mm}) \\
\text { Chewiness }(\mathrm{gr}) \\
\text { Guminess }(\mathrm{gr}) \\
\text { Adhesiveness }(\mathrm{gr})\end{array}$ & $\begin{array}{c}371 / 66 \pm 55 / 44^{\mathrm{a}} \\
0 / 28 \pm 0 / 034^{\mathrm{a}} \\
6 / 36 \pm 1 / 06^{\mathrm{a}} \\
6 / 66 \pm 2 / 38^{\mathrm{a}} \\
104 / 40 \pm 21 / 57^{\mathrm{a}} \\
1 / 52 \pm 1 / 02^{\mathrm{c}}\end{array}$ & $\begin{array}{c}503 / 25 \pm 42 / 75^{\mathrm{a}} \\
0 / 23 \pm 0 / 010^{\mathrm{a}} \\
6 / 54 \pm 0 / 56^{\mathrm{a}} \\
7 / 40 \pm 1 / 04^{\mathrm{a}} \\
114 / 73 \pm 6 / 50^{\mathrm{a}} \\
3 / 56 \pm 1 / 23^{\mathrm{b}}\end{array}$ & $\begin{array}{c}430 / 33 \pm 37 / 23^{\mathrm{a}} \\
0 / 23 \pm 0 / 051^{\mathrm{a}} \\
6 / 10 \pm 0 / 68^{\mathrm{a}} \\
5 / 78 \pm 0 / 68^{\mathrm{a}} \\
97 / 46 \pm 15 / 10^{\mathrm{a}} \\
3 / 96 \pm 0 / 87^{\mathrm{b}}\end{array}$ & $\begin{array}{c}499 / 50 \pm 9 / 50^{\mathrm{a}} \\
0 / 27 \pm 0 / 0057^{\mathrm{bc}} \\
6 / 01 \pm 0 / 58^{\mathrm{a}} \\
8 / 08 \pm 0 / 77^{\mathrm{a}} \\
137 / 20 \pm 0 / 30^{\mathrm{a}} \\
3 / 35 \pm 0 / 86^{\mathrm{b}}\end{array}$ \\
\hline
\end{tabular}

Similar letters describe no significant differences $(\mathrm{p}<0.05)$

SFC: cheese produced by whole milk contains $3.5 \%$ fat

LFS : cheese produced by milk contains $0.93 \%$ fat without malt extraction

$\mathrm{X} 1$ : cheese produced by milk contains $0.93 \%$ fat and adding $0.075 \%$ malt extraction

X2: cheese produced by milk contains $0.93 \%$ fat and adding $0.1 \%$ malt extraction

X3: cheese produced by milk contains $0.93 \%$ fat and adding $0.15 \%$ malt extraction

$\mathrm{X} 4$ :cheese produced by milk contains $0.93 \%$ fat and adding $0.2 \%$ malt extraction

\section{Punching}

LFC's hardness was significantly more than SFC and other treatments $(p>0.05)$.Adding malt extract to cheese cause to soften texture and less required force for penetrating. X4 had the least hardness among treatments $(16,19)$.

\section{Cutting}

Table 2 displays the results of cutting test as it has shown, the most and the least hardness observed in LFC (significantly differed from other treatments) and X4 respectively . 
Table. 2. Comparison of averages of different malt extraction concentration on textural properties of UF fresh cheese

\begin{tabular}{|c|c|c|c|c|c|}
\hline Parameters & Sample & \multicolumn{4}{|c|}{ Day } \\
\hline & & 3 & 20 & 40 & 60 \\
\hline \multirow[t]{6}{*}{ Punching (gr) } & SFC & b70/83 $\pm 10 / 61$ & $\mathrm{a} 64 / 00 \pm 2 / 00$ & b79/66 $\pm 5 / 13$ & b74/66 $\pm 1 / 25$ \\
\hline & LFC & 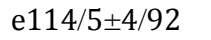 & d159/33 $\pm 1 / 60$ & $\mathrm{~d} 118 / 83 \pm 3 / 75$ & $\mathrm{~d} 141 / 00 \pm 3 / 60$ \\
\hline & $\mathrm{X} 1$ & $\mathrm{~d} 102 / 00 \pm 1 / 50$ & 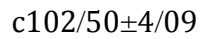 & $\mathrm{d} 110 / 16 \pm 9 / 82$ & c102/33 $\pm 1 / 04$ \\
\hline & $\mathrm{X} 2$ & 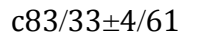 & 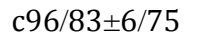 & c95/16 $\pm 3 / 40$ & c100/66 $23 / 40$ \\
\hline & X3 & c81/83 $\pm 5 / 34$ & b82/50 $\pm 11 / 50$ & b79/50 $\pm 7 / 05$ & b71/83 $\pm 8 / 96$ \\
\hline & $\mathrm{X} 4$ & $\mathrm{a} 54 / 00 \pm 4 / 00$ & b77/66 $\pm 6 / 21$ & $a 59 / 00 \pm 2 / 78$ & $\mathrm{a} 60 / 33 \pm 4 / 07$ \\
\hline \multirow[t]{6}{*}{ Cutting (gr) } & SFC & a32/50 $\pm 2 / 78$ & a32/16 $\pm 0 / 76$ & a35/33 $\pm 4 / 07$ & a32/83 $\pm 1 / 60$ \\
\hline & LFC & $\mathrm{d} 109 / 83 \pm 5 / 57$ & d117/83ะ2/84 & $\mathrm{d} 111 / 00 \pm 7 / 93$ & $\mathrm{~d} 112 / 00 \pm 8 / 67$ \\
\hline & $\mathrm{X} 1$ & c97/33 $\pm 2 / 02$ & $\mathrm{c} 102 / 50 \pm 11 / 50$ & $\mathrm{~d} 104 / 00 \pm 2 / 64$ & 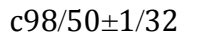 \\
\hline & $\mathrm{X} 2$ & c91/66 $\pm 5 / 68$ & 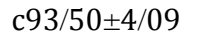 & c92/66 $23 / 25$ & c95/66 $\pm 2 / 84$ \\
\hline & X3 & b70/33 $\pm 3 / 40$ & b73/16 $\pm 2 / 36$ & b70/00 $\pm 5 / 26$ & b69/83 $\pm 8 / 25$ \\
\hline & $\mathrm{X} 4$ & a38/00 $\pm 5 / 63$ & $\mathrm{a} 41 / 33 \pm 3 / 01$ & a39/00 $\pm 3 / 77$ & $\mathrm{a} 40 / 16 \pm 4 / 25$ \\
\hline
\end{tabular}

SFC: cheese produced by whole milk contains $3.5 \%$ fat Similar letters describe no significant

LFS : cheese produced by milk contains $0.93 \%$ fat without malt extraction

$\mathrm{X} 1$ : cheese produced by milk contains $0.93 \%$ fat and adding $0.075 \%$ malt extraction

X2: cheese produced by milk contains $0.93 \%$ fat and adding $0.1 \%$ malt extraction

X3: cheese produced by milk contains $0.93 \%$ fat and adding $0.15 \%$ malt extraction

$\mathrm{X} 4$ :cheese produced by milk contains $0.93 \%$ fat and adding $0.2 \%$ malt extraction

\section{Conclusion}

The results of this research revealed that some textural properties of low fat UF cheese influenced by adding malt extract in which led to intake more water, followed by creating a decreasing rate of all TPA measured parameters including Hardness, Cohesiveness, Springiness, Chewiness, Gumminess, Punching, Cutting X4 showed the most resemble properties of SFC .therefore applying malt extract can produce cheese like properties.

\section{Abbreviation \\ UF = Ultra Filtration}

\section{References}

(1) Aly ME. 1997.Malt extract for enhancing flavour development of ultrafiltered Domiati cheese. Food Chemistry;Vol,59 .No,1. pp, 127133.

(2) Bourne MC. Food texture and viscosity: Concept and Measurement. 2nd ed. Translated by Abbasi S. Tehran. Press; 2008. [in Persian].

(3) Codex Alimentarius Commission A-19 : 1997 Standard for Unripened Cheese Including Fresh Cheese.

(4) Costa NE, Hannon JA, Guinee TP, Auty MAE, Mcsweeney PLH, Beresford TP. 2010.Effect of exoplysaccharide produced by isogenic strains of Lactococcus lactics on half-fat cheddar cheese. Journal of Dairy Science .Vol ,93.No ,1 .pp, 3469- 3486.

(5) Fox PF, Guinee Tp, Cogan TM, Mcsweeney PLH. Fundamentals of cheese science. Aspen publishers, Inc: 2000.

(6) Ghods Rohani M, Mortazavi SA, Mazaheri Tehrani M, Razavi MA. 2012Effect of processing conditions on textural properties of ultrafiltrated Feta cheese made from cow's milk and soymilk blend. Journal of Food Science and Technology .Vol,36.No,9.

(7) Gunasekaran S, Mehmet Ak M. Cheese Rheology and Texture. CRC press LLC: 2003.

(8) Institute of Standards and Industrial Research of Iran, Milk and milk products- Determination of titrable acidity and value $\mathrm{pH}-$ Test method. ISIRI no 2852. 1rd revision, Karaj: ISIRI; 2006 [in Persian].

(9) Kavas G, Oysun G, Kinik O, Uysal H. 2004.Effect of some fat replacers on chemical, physical and sensory attributes of low-fat white pickled cheese. Food Chemistry; 88: 381-388.

(10) Koca N, Metin M. Textural, melting and sensory properties of lowfat fresh kashar cheese produced by using fat replacers. International Dairy Journal Vol ,14.pp. 365-373.
(11) Lashkari H, Khosrowshahiasl A, Golkari H, Ashrafiyourganlo R, Zohri M. 2008.0ptimizing chemical and rheological attributes of low-fat Iranian white-brined cheese by using guar gum and gum Arabic as fat replacers. Iranian Journal of Nutrition Sciences \& Food Technology.Vol ,3.No,3.pp,1-10[in persian].

(12) Lobato-Calleros C, Rodriguez E, Sandoval- Castilla O, VernonCarter EJ, Alvarez- Ramirez J. 2006.Reduced-fat white fresh cheeselike products obtained from w1/ o / w2 multiple emulsions: Viscoelastic and high- resolution image analyses. Food Research International. Vol ,39.pp, 678-685.

(13) Miocinovic J, puda P, Radulovic z, pavlovic V, Miloradovic Z, Radovanovic M, et al. 2011. Development of low fat UF cheese technology. Mljekarstvo.Vol ,61.No,1.pp, 33 - 44.

(14) Mistryvv, Metzger LE, Mauboist JL. 1996.Use of Ultrafiltered Sweet Buttermilk in the manufacture of Reduced fat cheddar cheese. Journal of DairyScience.Vol, 79.pp,1137- 1145.

(15) Rashidi H, MazaheriTehrani M, Razavi SMA, GhodsRohany M. 2011.The Effect of Fat-Reduction and Cacl2 Levels on Sensory and Textural Characteristics of UF-Feta Cheese Made from Retentate Powder of Milk Ultra Filtration. Iranian Food Science and Technology Research JournalVol , 7.No, 3.pp, 218-226 [in persian].

(16) Romieh EA, Michaelidou A, Biliaderis CG, zerfiridis GK. 2002.LowFat white-brine cheese made from bovine milk and two commercial fat mimetics. Chemical, Physical and Sensory attributes. International Dairy Journal.Vol, 12.pp ,525- 540.

(17) Sahan N, Yasar K, Hayaloglu AA, karaca OB, kaya A. 2007.Influence of fat replacers on chemical composition, proteolysis, texture profiles, meltability and sensory properties of low-fat kashar cheese. Journal of Dairy Research.Vol,75.pp, 1-7.

(18) Sipahioglu o, Alvarez VB, Solano- Lopez C. 1999.Structure, physicchemical and sensory properties of feta cheese mode with tapioca starch and lecithin as fat mimetics. International Dairy Journal .Vol,9.pp, 783-789.

(19) Tunick MH. 2000.Rheology of Dairy Foods that Gel, Stretch, and Fracture. J Dairy Science Vol, 83.pp, 1892-1898.

(20) Vithange CJ, Mishra VK, vasiljevic T, shah NP. 2008. Use of $\beta$-glucan in development of low-fat mozzarella cheese. Milchwissenschaft.Vol,63 .No,4.

(21) Volkakis P, Biliaderis CG, Vamvakas C, Zerfiridis GK. 2004.Effect of a commercial oat- $\beta$-glucanconcentrate on the chemical, physicochemical and sensory attributes of a low-fat white-brined cheese product. Food Research International.Vol, 37.pp,83-94.

(22) Zisu B, Shah NP. 2005.Textural and functional changes in low-fat Mozzarella cheeses in relation to proteolysis and microstructure as influenced by the use of fat replacers, pre-acidification and EPS starter. International Dairy Journal. Vol , 15.pp, 957-972. 